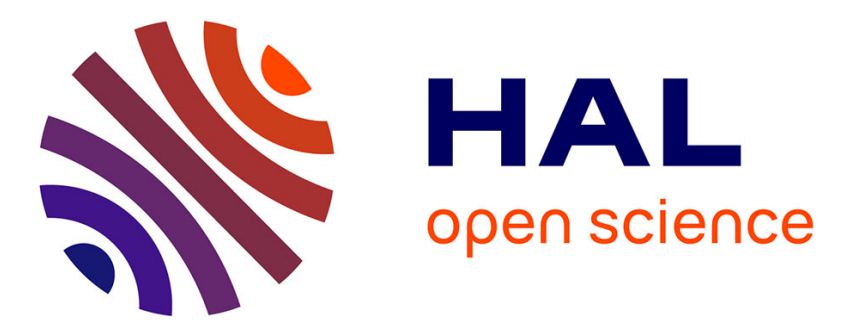

\title{
Provincial public expenditure in China: a tale of pro-cyclicality
}

Jean-Louis Combes, Mary-Françoise Renard, Sampawende J.-A. Tapsoba

\section{To cite this version:}

Jean-Louis Combes, Mary-Françoise Renard, Sampawende J.-A. Tapsoba. Provincial public expenditure in China: a tale of pro-cyclicality. Economic Change and Restructuring, 2019, pp.19-41. 10.1007/s10644-017-9215-4 . hal-01727900

\section{HAL Id: hal-01727900 \\ https://hal.science/hal-01727900}

Submitted on 7 Dec 2021

HAL is a multi-disciplinary open access archive for the deposit and dissemination of scientific research documents, whether they are published or not. The documents may come from teaching and research institutions in France or abroad, or from public or private research centers.
L'archive ouverte pluridisciplinaire HAL, est destinée au dépôt et à la diffusion de documents scientifiques de niveau recherche, publiés ou non, émanant des établissements d'enseignement et de recherche français ou étrangers, des laboratoires publics ou privés. 


\title{
Provincial Public Expenditure in China: A Tale of Pro-cyclicality
}

\author{
Jean-Louis Combes, Mary-Françoise Renard (IDREC-CERDI, \\ Université d'Auvergne),
}

Sampawende J.-A. Tapsoba (IMF, Washington DC)

\begin{abstract}
This paper examines the cyclicality of provincial expenditure in China during the period 1978-2013. Using panel data for analysis, it assesses whether provincial expenditure has been pro-cyclical. Pro-cyclicality is found to be a regular feature of provincial fiscal policy. This pro-cyclicality occurs both in times of low and high growth rates and has markedly intensified since 1994 with the increased autonomy of provinces. The paper further finds that the pro-cyclicality bias is mitigated when financial constraints are relaxed, the remaining political life of the governor is long, government efficiency is strong, corruption incidence is low, and governments are large.

JEL Codes: E62, H50, H60, R12.

Keywords: China, Fiscal cyclicality, Regional growth.
\end{abstract}

\section{Introduction}

Existing evidence points to widespread use of pro-cyclical fiscal policy in developing and emerging countries (Gavin and Perotti, 1997; Tornell and Lane, 1999; Lane, 2003; Talvi and Végh, 2005; Ilzetzki and Végh, 2008). The literature explains this tendency mostly by the imperfect access to international credit markets and lack of financial depth ${ }^{1}$ and weak

\footnotetext{
${ }^{1}$ Difficulties in accessing capital markets during recessions often force governments in developing countries to refinance or repay debt, obliging them to embark on contractionary policies (Gavin and Perotti, 1997; Caballero and Krishnamurthy, 2004).
} 
institutions ${ }^{2}$. Such procyclicality can in theory have large welfare and macroeconomic effects (Christiano et al., 2011). ${ }^{3}$

The role of subnational governments has received little attention in the literature (e.g. Rodden and Wibbels, 2010). ${ }^{4}$ With increasing trends in decentralization around the world, the conduct of fiscal policy over the business cycle at the local level has recently received more attention. As for central fiscal authorities, the literature shows that local governments are inherently pro-cyclical because of relative tougher financing constraints and misalignment of policy objectives between local and central governments. Rodden and Wibbels (2010) examined the sensitivity of provincial government budgets to regional business cycles in seven countries with federal systems (Argentina, Australia, Brazil, Canada, Germany, India, and the United States). They argued that local governments are more pro-cyclical than central fiscal authorities because of their limited insurance (mostly via transfers from central government) against regional shocks, and restraints on borrowing and saving. Especially, few papers focused on China. Carmignani and Laurenceson (2013) showed that aggregate provincial expenditures were systematically pro-cyclical during the 1978-2008 period. Understanding whether China's provinces pursue pro-cyclical fiscal policies and the potential drivers is therefore important. The case of China is particularly interesting because of its strong economic decentralization, and the key role devoted to local governments in its overall growth agenda. China's decentralization process is characterized by a relatively stronger autonomy for the provinces and a rating system of the governors that could encourage to adopt more active fiscal policies.

Chinese local governments are more powerful than their counterparts in other federal countries. They play a much more central role in local economies than their peers elsewhere. They can levy taxes, decide and implement budgets, and exercise substantial controls over the allocation of bank credits. The relative strong autonomy of the provinces can result in a more activist and pro-cyclical fiscal policy at the subnational level. Decentralization in China began with the delegation of a large economic authority to local governments (Montinola, Qian and Weingast, 1995). Many reform policies (including price liberalization and opendoor policy), and the oversight of state-owned enterprises were delegated to local governments. The provinces are also responsible of the conduct of fiscal policy with the responsibility of providing public services and the control of substantial portion of provincial fiscal resources. More autonomy was granted to Chinese sub-national governments with the

\footnotetext{
${ }^{2}$ Weak institutions encourage ineffective and often inappropriate spending of revenue windfalls, leaving countries with inadequate buffers to cope with adverse shocks (Tornell and Lane, 1999; Talvi and Végh, 2005).

${ }^{3}$ Theoretical work by Christiano et al. (2011) clearly suggests that this shift in the cyclical properties of fiscal policy is welfare improving since the optimal fiscal policy in a stochastic model with sticky prices is countercycical.

${ }^{4}$ Rodden and Wibbels (2010) showed that procyclical fiscal policy among provincial governments offset the modest insurance against regional income shocks provided by central governments.
} 
1994 reforms. ${ }^{5}$ Before 1978, the central/local fiscal relationship was mostly based on the system of "eating from one pot". At that time, fiscal functions were carried on at the central government level with provincial fiscal policy consisting of collecting and remitting taxes (Feltenstein and Iwata, 2005). Since the end of the Cultural Revolution, Chinese provinces have gradually gained significant fiscal autonomy. After 1978, several additional functions were transferred to provincial governors. Decentralization was first based on a fiscal contract system from 1980 to 1993, and then on a revenue assignment system from 1994 to date, generating a vertical fiscal imbalance bias in favor of relative to rich provinces. Poor provinces might rely on relatively lower resources (due to capacity and development level) to fund mandatory expenditure assignments (Eyraud and Lusinyan 2013).

In addition, because of the "rating" mechanisms of local leaders, there are further incentives to run procyclical fiscal policies. Even though a significant autonomy was granted to provincial authorities, the central government still exerts some influence over provincial fiscal policies through the designation and a rating system of provincial leaders $(\mathrm{Xu}, 2011 ; \mathrm{Li}$ and $\mathrm{Wu}, 2012) .{ }^{6}$ In this organizational structure, the central government has a strong instrument to control the provincial governments and to give incentives to apply its own economic policy: it chooses, appoints, and rewards the provincial leaders. The opportunity for promotion is a strong incentive to embark on large spending and infrastructure projects. ${ }^{7}$ Because of the link established between the provincial governors' promotion and the growth rate, local authorities face a rating system that provides strong incentives to actively use fiscal policy to spur growth in the short run irrespective of the cycle.

This paper examines the issue for China, and focuses on the cyclicality of fiscal policy at the provincial level. We use an innovative and robust econometric method to assess the cyclical pattern of provincial public expenditure in China and its determinants over the 1978-2013

\footnotetext{
${ }^{5}$ With the 1994 reforms, the autonomy of provincial governments increased significantly. In 1994, China introduced a major tax and fiscal reform program known as the tax assignment system to replace the discretionary fiscal contract system. This new scheme recentralized much of the tax revenues. The upper-level governments have the decisive power over the fiscal schemes of their directly subordinate governments with little discretion of the central government (Jia et al., 2014). There are 5 hierarchical levels: Central, provincial, prefectural, county, and township. This fiscal reform was a milestone in China's intergovernmental relations, and largely reshaped the incentives of local government in economic development. Changing the resourcesharing system was to the advantage of the provincial governments; and the Central government focused more on the coordination and implementation of national economic policies (Naughton and Yang, 2010).
}

\footnotetext{
${ }^{6}$ Oversight from the central government certainly plays an important role, as emphasized by Xu (2011). Local officials are appointed by higher levels of government officials, and are evaluated by the central government based on a range of criteria. On the one hand, this system of appointment and promotion of provincial leaders serves as a powerful instrument for the national government to induce regional officials to follow the central government policies. On the other hand, the hierarchical administrative organization induces a shared authority, which is beneficial to the local governments.

${ }^{7}$ For instance, from 1992 to 2008, every president, every premier, every newly elected Politic Bureau Standing Committee member of the four CCP congresses during this period was promoted from a provincial position $(\mathrm{Xu}, 2011)$.
} 
period. More specifically, it addresses two issues: (i) whether the procyclicality documented by existing papers is associated with spending items and (ii) explore the underlying driving factors. To this end, an original dataset covering proxies of financing constraints, institutional quality, and characteristics of provincial leaders was compiled. In therefore, doing we are not only able to qualify the cyclicality of provincial expenditure items, but identify possible mechanisms that drive the cyclicality of fiscal policy at the provincial level.

We find that all provinces are characterized by pro-cyclical spending across all subcategories of spending, except for innovation funds, which are acyclical. Moreover, this procyclicality occurs both in times of low and high growth rates and has markedly intensified since the increased autonomy given to provinces in 1994. Only one third of provinces have avoided the pro-cyclicality trap since the reform. Estimates indicate that the pro-cyclicality bias is mitigated when financial constraints are relaxed, the remaining political life (RPL) of the governor is long, government efficiency is strong, corruption incidence is low, and governments are large.

This paper brings several key contributions to the literature. This is the first paper to examine the cyclicality of expenditure subcategories of Chinese subnational public expenditure. A disaggregated approach is key to understand the cyclical behavior of fiscal policy and avoid misleading conclusion based on broad aggregates. The second contribution is the analysis of the effects of the 1994 reform towards more autonomy of the local governments in China. The third contribution is the exploration of the drivers of the cyclicality of provincial fiscal policy. In this context, we compile an original dataset on Chinese provinces including public expenditures and their subcomponents, financial development, political characteristics of provincial governors, quality of institutions and governance, and some structural factors.

The rest of the paper is organized as follows. The next section discusses the role of the institutional arrangements between the central and local governments in the cyclicality of provincial expenditure. Section III presents the potential drivers of cyclical fiscal policy at the provincial level in China. Section IV explains the empirical strategy used. The dataset is described in section V. The results are discussed in section VI, and section VII offers conclusions.

\section{Empirical strategy}

There is a well-developed empirical literature on assessing the cyclicality of fiscal policies, which we broadly follow in our approach (Talvi and Végh, 2005; Ilzetzki and Végh, 2008; Alesina et al., 2008). The follow a two-step strategy.

\subsection{First step}

The starting point for estimating the cyclicality of provincial fiscal policies, a fiscal reaction 
function of the following general form is estimated:

$G_{\mathrm{i}, t}=\alpha+\beta Y_{i, t}+\delta G_{i, t-1}+\eta_{i}+\mu_{t}+\xi_{i, t}$

where $i$ and $t$ represent province and period, respectively. $G_{i, t}$ is the indicator of fiscal policy. Most studies on developing countries focus on the growth or level of public expenditure (instead of revenue) because of its exogeneity. ${ }^{8}$ Since the automatic stabilizers are likely to be small at the provincial level, equation (1) is a reasonable approximation of discretionary fiscal policy. $Y_{i, t}$ represents the output cycle, defined as output gaps or growth rates; and $v_{i, t}$, the disturbance term, captures fiscal shocks. The disturbance term is the sum of three orthogonal components: province and year fixed effects, $\eta_{i}, \mu_{t}$, and an idiosyncratic fiscal shock, $\xi_{i, t}$.

The above fiscal reaction function can be reformulated as a Taylor-type rule without the inflation terms, as suggested by Calderón et al. (2004). This Taylor-type reaction function assesses the direction and level of co-movements between government expenditure and output deviations from their respective steady-state trends.

$G_{i, t}-G_{i, t}^{*}=\alpha+\beta\left(Y_{i, t}-Y_{i, t}^{*}\right)+\delta\left(G_{i, t-1}-G_{i, t-1}^{*}\right)+v_{i, t}$

The superscript $*$ denotes the long-term trend of the government expenditure and output. $\left(G_{i, t}-G_{i, t}^{*}\right)$ denotes the deviation of actual government expenditure from its long-term trend, $\left(Y_{i, t}-Y_{i, t}^{*}\right)$ denotes the deviation of output (or real GDP) from its long-term trend, and $\beta$ denotes the short-term fiscal response to the economic cycle.

To estimate equation (2), a measure of the unobserved long-term values of government expenditure and output is required. One approach would be to use a dynamic equation with the lagged values of these variables used as proxies for the long-term values and run the regression in first difference (as in Lane, 2003 and Thornton, 2008). ${ }^{9}$ The literature has focused on the relationship between the growth rate of government expenditure and output by considering the natural logarithmic specification. This gives equation (3), which we adopt as our baseline model:

$$
\Delta \log G_{i, t}=\alpha+\beta \Delta \log Y_{i, t}+\delta \Delta \log G_{i, t-1}+v_{i, t}
$$

\footnotetext{
${ }^{8}$ The ideal way to analyze the cyclicality of tax revenue is to focus on the cyclicality of tax rates because they are the true measures of the fiscal actions without the effect of automatic stabilizers (Kaminsky, Reinhart, and Végh, 2005). A procyclical fiscal policy with respect to taxes is defined as increases in tax rates during recessions and reductions in tax rates during expansions (i.e., a negative correlation of tax rates with the business cycle). Unfortunately, there is no readily available data on conventional tax rates for Chinese provinces. Hence, we focus on the expenditure data which are less prone to the effect of automatic stabilizers.

${ }^{9}$ Results with alternative filters (Baxter-King, Christiano-Fitzgerald, and Hodrick-Prescott filters) are provided in the robustness section.
} 
The operator $\Delta$ is the first difference operator and $\log$ is the natural logarithm. The cyclicality of fiscal policy is then determined by looking at the sign and the size of the coefficient $\beta$, which captures the short-term cyclical behavior of government expenditure and could be expressed as the first derivative of changes in expenditure with respect to changes in output, $\beta=\frac{\partial \Delta \log G_{i, t}}{\partial \Delta \log Y_{i, t}}$. When the indicator of fiscal policy is expressed in terms of government expenditure, pro-cyclicality is assumed in the data if $\beta>0$ and statistically significant, i.e. a cyclical upturn (downturn) is associated with an increase (decrease) in government expenditure; counter-cyclicality if $\beta<0$; and acyclicality if $\beta=0$. The coefficient $\delta$ captures possible inertia effects in government expenditure. This coefficient is expected to have a positive sign and be less than 1 .

Admittedly, estimating equation (3) is challenging because of the potential endogeneity. The first One challenge is the reverse causality between provincial expenditure and output (since output is likely to be responsive to a fiscal stimulus, as explained by the standard neoKeynesian model). To address these endogeneity issues, the existing literature makes use of external instruments such as the weighted growth of the main trading partners. Unfortunately, such a series is difficult to construct for China because of the lack of data on intra-Chinese trade. Another technique often used in the literature is the generalized method of moments (GMM), which is particularly suitable for dynamic panels. An additional challenge is the possibility that some omitted variables may be correlated with both output and government expenditure, which may also result in biased estimates. We therefore use the within fixed effect (FE) estimator, which mitigates the simultaneity and omitted variables biases by controlling for time invariant idiosyncratic factors. ${ }^{10}$ The lagged dependent variable is correlated with the error terms, leading to the well-known Nickell's (1981) bias. To assess the influence of the possible Nickell's bias, the FE estimation of equation (1) is conducted with and without the lagged dependent variable. In addition, controlling for province and year fixed effects should limit the potential endogeneity problem by controlling for (i) unobserved time-invariant factors that affect both GDP growth and government spending growth within a province and (ii) time-varying factors that affect GDP growth and government spending commonly across the provinces (or in the average province). All estimates correct for the autocorrelation and the heteroskedasticity.

\subsection{Second step}

In the second step, the determinants of the cyclicality of provincial expenditure are analyzed. We allow the $\beta$ coefficient to be province specific and time varying, as specified in equation in (3). Following Aghion and Marinescu (2008), we estimate equation (3) using local Gaussian-weighted ordinary least squares. This technique determines the time-varying cyclicality coefficient $\hat{\beta}_{i t}$ for province $i$ at year $t$, by using all observations and assigning

\footnotetext{
${ }^{10}$ However, controlling the time invariant factors can at most solve part of the omitted variables problem, as some omitted variables may be changing over time.
} 
greater weights to those observations closest to the reference year. This is achieved by giving a Gaussian-centered weight to the reference period. As in Aghion and Marinescu (2008), we apply a ten-year rolling period approach to ensure that the cyclicality captured is the result of transitory discretionary fiscal policies. If $\tau$ denotes the length of the rolling period, then the error term $\vartheta_{i t}$ follows a normal distribution function: $N\left(0, \sigma^{2} / w_{t}(\tau)\right.$ with $w_{t}(\tau)=$ $\frac{1}{\sigma \sqrt{ }(2 \Pi)} \exp \left(-\frac{(\tau-t)^{2}}{2 \sigma^{2}}\right), \tau \in(t-5, t+4) .{ }^{11}$ In the second step, we pool the estimated timevarying cyclicality coefficients $\left(\hat{\beta}_{i t}\right)$, and regress them against the vector of control variables that are thought to be the main drivers of cyclicality in developing provinces (as noted in the literature above). This is represented in equation (4)

$\hat{\beta}_{i t}=\gamma+\sum_{j=1}^{J} \lambda_{j} X_{j i t}+\theta_{i}+\theta_{t}+\varepsilon_{i t}$

$X_{j}$ denotes the factors of interest. $\theta_{i}$ and $\theta_{t}$ are the province and year fixed effects, respectively. $\varepsilon_{i t}$ is the error term. Equation (4) is estimated with the weighted least squares technique using the inverse of the standard deviation of $\hat{\beta}_{i t}$.

According to the literature, various factors can explain the pro-cyclical nature of fiscal policies. For Chinese provinces, the dominant drivers would be related to financing constraints, political factors and institutional quality, as well as exposure to shocks and structural factors.

Financing constraints. The inability to borrow forces local authorities with tax-raising powers to cut expenditure in bad times; similarly, when cheap and easy financing is available there is a strong incentive for fiscal authorities to increase expenditure. It must be noted that a deficit is not allowed for Chinese provinces; but they got around this rule for a time by creating financing vehicles - these are now forbidden because of the growing debt of the provinces. For some years, it was a way to find funds. Good data are not available, but it is reasonable to consider that these funds might mitigate the pro-cyclicality of the expenditure of the provincial governments in the short term, but undermine fiscal sustainability in the long term. We expect the degree of financial development at the provincial level to be a mitigating factor of fiscal pro-cyclicality.

Political factors. Local political factors may drive the cyclicality of subnational expenditures. For Chinese provinces, the political factors are likely to have an effect mostly at the Governor level. In China, governors are at the heart of regional economic policy. They have strong powers in their province, but their career depends on the central government. Given the absence of a formal democratic election system for governors in China, one can argue that the appointment process and some characteristics of governors could capture the political factors related to the rent-seeking behavior. In the estimates, we use three proxies for political factors: the turnover of governors, the duration of the governors' tenure, and the

\footnotetext{
${ }^{11}$ The smoothing parameter $\sigma$ is arbitrarily set to 5 because the results are qualitatively robust to slight changes in this parameter.
} 
RPL according to the Chinese communist party implicit rule (see the Dataset section). First, the degree of turnover, the period in office, and the RPL could capture the extent to which governors and are held more accountable for their actions at the provincial level. The role of governor turnover in the cyclical pattern of provincial expenditure is a priori ambiguous. On the one hand, the risk of turnover could create incentives for optimal (a cyclical or countercyclical) policy (a disciplining effect). On the other hand, the risk of turnover could reduce the ability of governors to resist the demands of pressure groups in favor of a sloppier fiscal policy and lead to pro-cyclical fiscal policy (a moral hazard effect). Second, the number of years of tenure of office has an ambiguous effect on the design of optimal fiscal policy. The longer the period in office of a governor, the more the governor has allies in the central government or the central party, and the less is his sensibility to the performancebased promotion scheme in force in China since 1978. In that context, there is a risk of avoidance and rent-seeking in the implementation of fiscal policy since a governor is likely to conduct policy independent of the interest of his province. Fiscal policy is then prone to be pro-cyclical. Moreover, according to the performance-based promotion scheme, the longer the mandate is, the better the results of the economic policies are. Then, governors that stay longer in office could be encouraged to adopt optimal local fiscal policy. Third, the remaining political life, the likelihood of remaining in charge makes the governor more susceptible to political pressure: a newly-appointed governor could more easily promote procyclical policy, but having a longer RPL could induce the leader to pursue a more prudent fiscal policy to help his career.

Quality of institutions and governance. The quality of institutions is a key parameter, which shapes the management of fiscal policy over the business cycle (Calderón et al., 2012; Frankel, Végh and Vuletin, 2013). For Chinese provinces, we measure institutional quality by a set of indicators - government efficiency, fiscal transparency, the degree of marketization of the economy at the provincial level, and corruption. Better efficiency would ensure a better bureaucratic quality and a stronger capacity to deploy the desired policy. Likewise, a market-oriented economy would imply less distortions caused by government interventions, and stronger law and order enforcement. Better fiscal transparency would tend to mitigate the pro-cyclicality bias and the rent-seeking behavior. Corruption is another key dimension of the quality of institutions, which affects the cyclicality of public expenditures (Alesina et al., 2008 Thornton, 2008). Corruption is a big problem in China, and the Central government has implemented a large program to fight it, which underlines the depth of this problem in the past. The extent of corruption is especially important in view of the decentralization, because local leaders have a large discretion over which laws to implement (Birney, 2014). Better governance may be correlated with less fiscal pro-cyclicality if it increases the tax revenues available for countercyclical expenditure.

Structural factors. Beyond the above-mentioned factors, there are structural factors that influence the conduct of fiscal policy over the business cycle. The size of the public sector is a good example, although its influence is not clear cut. According to the literature on automatic stabilizers, large provincial governments tend to embark on countercyclical policy (lower procyclicality) which is associated with lower growth volatility (van den Noord, 2000). The level of development is another structural factor that matters. Lane (2003) argued that the stage of development has a systemic influence on fiscal pro-cyclicality. This is 
particularly premised on the fact that the technical capacity to implement the intended cyclical policy is dependent on the development stage. There are also findings in the literature which suggest that the degree of output instability constrain the ability of fiscal authorities to conduct countercyclical fiscal policy (Lane, 2003; Talvi and Végh, 2005). In addition, trade openness matters for the conduct of fiscal policy because it magnifies the vulnerability to shocks. If open economies are vulnerable to risk, as argued by Rodrik (1998), it may be especially important for the government to facilitate consumption smoothing by operating a countercyclical policy. The underlying idea is that more open economies are intrinsically more susceptible to external shocks, which creates public demand for countercyclical fiscal policy. As such, we anticipate that governments facing high output volatility may find it optimal to pursue pro-cyclical fiscal policies. Finally, the initial fiscal position could play a role. ${ }^{12}$ On the one hand, a strong fiscal deficit could incite the province to adopt a more prudent policy and reduce the pro-cyclicality. On the other hand, initial deficits could also indicate low governance quality and greater likelihood that the government cannot borrow in future recessions.

\section{Dataset}

The primary data source for this paper is China Data Center (http://chinadataonline.org/). We collect, at the provincial level, information on Gross Domestic Product (GDP), government expenditure and revenue, Consumer Prices Index (CPI), bank loans and deposits, and imports and exports, from 1978 to 2013. Output, expenditure (and its subsequent components such as expenditure for administration, capital construction, innovation funds, agriculture support, and social systems i.e. culture, health and education), and revenue are expressed in current Yuan. All fiscal variables are converted into constant prices using the CPI, since we do not want to eliminate any growth in provincial expenditure that takes the form of an increase in the relative price of public sector outputs. The trade openness indicator is calculated as the sum of imports and exports divided by GDP. We follow Talvi and Végh (2005) by including output volatility, which is measured as the standard deviation of the GDP growth rate using a 5 -year rolling period. The size of the public sector measured as the average ratio of provincial expenditure to GDP. The level of per capita GDP is included to control for potential of development.

Other information on the drivers are compiled from various sources. First, we use a loan to deposit ratio as a proxy of financial development for each of the Chinese provinces. Ideally we would have preferred a variable that captures better the financial constraint faced by the provincial government such as the provincial debt which has increased markedly in the recent period (Zhang and Barnett, 2014; Ang, Bai, and Zhou 2016). Unfortunately, consistent historical data on provincial debt is not available. As a second-best indicator, we assume that a measure of the financial constraint faced by the private sector could capture differences in

${ }^{12}$ The ideal control for the initial fiscal position is local public debt which has increased markedly in the recent period (Zhang and Barnett, 2014; Ambrose, Deng, and Wu, 2016; Ang, Bai, and Zhou 2016). 
financial constrains faced by local public fiscal authorities. As shown by Ambrose, Deng, and $\mathrm{Wu}$ (2015), we conjecture that local financial development indicators are negatively correlated with local borrowing cost, even if financing vehicles are issued nationally. Second, we compile from different sources information on the quality of institutions: corruption, quality of provincial governance, and the degree of marketization. The extent of corruption is captured by the province level number of recorded cases under direct investigation by the people's procuratorates divided by the regional population (cases per 100,000 persons). These data from Cole et al. (2009) cover the period 1998-2003 and are based on the Procuratorial Yearbook of China. Recorded cases include people charged with corruption, bribery, misappropriation of public funds, collective illegal possession of public funds, undisclosed source of large property, abuse of power, dereliction of duty, and fraudulent practices. To capture the quality of provincial governance, we use the government efficiency index from Cole et al. (2009). This index is available from 1998 to 2003 and combines 40 separate indices covering all aspects of governance aggregated into four factors: public services, public goods, government size, and national welfare. The difference in government efficiency levels between Chinese provinces appears to be consistent with the disparity in regional economic development. ${ }^{13}$ For the degree of marketization, we draw on Fan et al. (2010) National Economic Research Institute (NERI) index of marketization of Chinese provinces, which was constructed to measure the degree of government regulation in Chinese provinces from 1998 to 2007. This index covers 5 main aspects of Chinese marketization: the relationship between the market and the government, the growth of the non-state economy, the development of product markets, the development of factor markets, and the market environment, including intermediaries and institutional and jurisdictional arrangements. Finally, the information on the career of governors is taken from the website www.rulers.org, which compiles the information on local and central leaders around the world. Their careers are proxied by three variables: a turnover variable which takes the value one at the year of at least one change of governor in each province (turnover), the number of years in office (tenure) and the RPL (remaining political life) to the next National people's congress (i.e the difference between the assumed retirement age of 65 and the age at the next congress).

The dataset comprises a maximum of 953 observations. On average, growth rates of provincial real expenditure and real output are on a par; expenditure-to-GDP ratio is estimated at about 15 percent; the deficit-to-GDP ratio is 4.8 percent; the loan-to-deposit ratio is 91.7 percent; the trade openness is 23.3 percent. On average, governors stay in office 2 years and their ages average at about 57.6 years. Their RPL is about 5.5 years. In terms of quality of institutions, on average, the corruption index is 3.3 cases per 100,000 persons, the government efficiency index is zero, and the NERI is 5.6.

The next section discusses the empirical section.

\footnotetext{
${ }^{13}$ In 2003, provinces with the highest scores are Beijing, Shanghai, Tianjin, Jiangsu, Jilin, Liaoning, Zhejiang and Heilongjiang, provinces that tend to be in eastern coastal regions or on China's borders. In contrast, inland provinces, such as Shanxi, Jiangxi, Henan, Hunan, Guangxi, Chongqing, Sichuan, Guizhou, Yunan and Gansu, tend to have relatively lower efficiency scores.
} 
See Table 1 .

\section{Estimation Results}

In this section, we discuss our key findings. To that effect, we assess the cyclicality of total expenditure and its components. We investigate the role of the phase of growth regime and the 1994 reform. Lastly we analyze the heterogeneity across provinces and the related driving factors.

\subsection{Cyclicality of expenditure}

\subsubsection{Baseline}

We first investigate whether sub-national public spending is acyclical, counter-cyclical or pro-cyclical, at the provincial level. We estimate equation (3).

Table 2 reports in the first two columns, the difference and system GMM of the cyclicality of real public expenditure across provinces. The optimal lag structure of internal instruments is 3. Based on the classical appraisal criteria, the GMM results are not internally consistent with our provincial dataset. The GMM technique is very sensitive to the risk of proliferation of instruments. Depending on the lags chosen, the number of instruments can be larger than the cross-sectional dimension and create an over-identification bias. The number of instruments outweighs the cross-sectional dimension, and the model is over-identified, with the probability for the Sargan-Hansen test of over-identifying restrictions being well above the accepted thresholds in the literature (even following Roodman's 2009 strategy). ${ }^{14}$ The results reported in Table 2 show that p-values of Hansen tests are 1. The issue is even more pronounced when splitting the sample or including interaction terms as done later in this paper.

The two last columns report the FE estimates of the equation (3) with and without the lagged dependent variable to assess the influence of the possible Nickell's bias discussed above. The results remain broadly stable suggesting that the bias does not alter significantly the estimates. Moreover, the Nickell bias diminishes asymptotically toward zero as the time dimension of the panel increases (Beck and Katz, 2011). In our case with 35 years of data,

\footnotetext{
${ }^{14}$ Simply by being numerous, instruments over fit the instrumented variables, failing to correct for their endogenous components and biasing the coefficient estimates toward those from non-incremental estimators. Therefore, the over-identification test is biased toward the null hypothesis of the validity of instruments. We found that the probability of the Hansen J-statistic test equals 1 in all cases.
} 
the Nickell bias is small giving support to the fixed effects results without the lagged dependent variable. Because of these reasons, as discussed above, the fixed effect estimator is preferred. We also re-estimate equation (3) using lagged GDP growth. The results remain broadly unchanged indicating that the results are not driven by reverse causality (Appendix 1).

We find that the coefficient associated with output growth is stable across both specifications. In addition, the R-squared remains unchanged at 0.6 with and without the lagged dependent variable. The results are like those in the empirical literature (Carmignani and Laurenceson 2013). There is strong evidence that provincial expenditure is pro-cyclical. The coefficient of output growth is positive, statistically significant at the 1 percent level, but below 1. A 1 percent increase in provincial output is associated with an increase in provincial public expenditure of 0.4 percent. In other words, a one standard deviation (i.e. 0.06) increase (decrease) in the output growth rate is associated with 0.02 increase (decrease) in spending. These estimates are robust to the use of a filtering technique to extract any cyclical components of output and expenditure (see Appendix 2). The coefficient of the output cycle remains positive, statistically significant at the 1 percent level, but below 1 . In what follows, we shed further light on the pro-cyclical nature of provincial public spending in China.

See Table 2.

\subsubsection{Spending categories}

We split provincial spending into capital and current expenditure and their subcomponents. A subcomponent approach is useful to understand how the pro-cyclical behavior plays out, and to help avoid reaching misleading conclusions that could arise from broad aggregates, especially if subcomponents move in offsetting ways (Lane, 2003). In the context of the Chinese provinces, we measure capital expenditure as the sum of capital construction and innovation funds. Current expenditure covers the remaining expenditure and includes support to agriculture, social expenditure (including culture, education, science, and health care), and expenditure related to government administration. The results are shown in Table 3 . We find that pro-cyclicality exists (and is statistically significant at the 5 percent level) when considering current expenditure and capital expenditure as dependent variables.

All sub-categories of current spending are found to be pro-cyclical. The pro-cyclicality of spending related to government administration is twice as high. As suspected, capital expenditure tends to be slightly more pro-cyclical than current expenditure. For a 1 percent increase in provincial output, capital expenditure tends to increase by 0.43 percent while current spending increases less, by about 0.37 percent. The pro-cyclicality capital expenditure is mostly driven by the changes in construction funds. Spending related to innovation funds are acyclical. Capital expenditure is more responsive to economic cycles, since in periods of low growth the government has more leeway to cut or postpone capital expenditure compared to current expenditure, which is often statutory in nature, already committed, or non-discretionary. 
See Table 3.

\subsubsection{Growth regimes}

We test whether the pro-cyclicality of provincial expenditure depends on the position of the economy in the cycle. Two complementary arguments are proposed in the literature to support the rationale of asymmetric conduct of fiscal policy over the business cycle. Talvi and Vegh (2005) suggested that fiscal pro-cyclicality may be fueled by political pressure to spend windfall revenues in good times. Whereas Gavin and Perotti (1997) suggested that the pro-cyclical behavior might arise in times of low growth when fiscal authorities are shut out of markets obliging them to cut expenditure. For China, we suspect that in periods of good times and high tax intake, the leaders will be more sensitive to political pressure for more expenditure. Moreover, financial constraints will relax in good times.

Distinguishing the phases of the business cycle in China might be tricky. The country has experienced steady two-digit growth rates over recent decades. In the paper, we use a simple rule by computing, for each province, the deviation from the average growth rate over the period 1978-2013 $\left(\mathrm{Y}^{*}\right) .{ }^{15}$ We generate a dummy variable taking the value 1 if the growth in year $\mathrm{t}$ is above $\mathrm{Y}^{*}$ and 0 otherwise. This dummy is interactive with the growth. The same approach is followed for the periods of growth below the average. The results are shown in Table 4.

We find that pro-cyclicality occurs in both phases of the cycle. The estimated coefficients for total expenditure significant at 1 percent and similar in magnitude at around 0.4 percent. Provincial expenditure consistently follows the cycle irrespective of periods of low or high growth rates for all categories of expenditure. As seen above, a 1 percent increase in provincial output is associated with a less than proportional increase in provincial public expenditure.

See Table 4.

\subsubsection{4 fiscal reform}

We explore the effect of the 1994 reform on the cyclicality of provincial expenditure. As discussed above, in 1994 a structural shift occurred in China's decentralization system. Provinces were given more autonomy which has an influence on the conduct of local fiscal policy. We introduce additively and multiplicatively (with $\Delta \log Y i t$ ), a dummy variable taking the value 1 after 1994 and 0 before. The results are shown in Table 5.

\footnotetext{
${ }^{15}$ Results with classic filters are broadly unchanged. Estimates are available upon request.
} 
It turns out that pro-cyclicality has markedly intensified with the increased autonomy of provincial leaders. The coefficient associated with $\Delta \log Y_{i t}$ is positive, statistically significant at the 1 percent level, and estimated at 0.23 . The coefficient associated with the interactive term is positive, statistically significant at the 1 percent level, and estimated at 0.45. In other words, cyclical pro-cyclicality almost tripled after 1994. A similar pattern is observed in the pro-cyclicality of current expenditure which more than doubled. The change is stronger for capital spending which moved from acyclical before 1994 to highly procyclical after the implementation of the reforms.

The reforms have resulted in more pro-cyclicality in provincial expenditure. With more autonomy over the expenditure assignments and revenue collection and the rating system described above, provincial fiscal authorities have used expenditure in procyclical way that is accelerating spending in periods of high growth and slowing it down in times of low growth.

See Table 5.

\subsubsection{Graduating class}

We explore the heterogeneity of pro-cyclicality among provinces, whether some provinces could mitigate the pro-cyclicality bias over time, especially after the 1994 reform despite the general trend of increasing pro-cyclicality documented above. In this regards, we follow Frankel et al. (2013) who showed that over the last decade, several developing countries were able to "graduate" in the sense of overcoming the problem of pro-cyclicality and becoming countercyclical.

For China, we estimate the province specific cyclical response of public spending to growth $\left(\hat{\beta}_{i}\right)$ over the period 1978-2013, and subsequently for 1978-93 and 1994-2013. Table 6 gives the value of the $\hat{\beta}_{i}$ coefficients by province, and highlights the changes over time of the cyclical coefficients. In line with the findings above, none of the provinces conduct a counter-cyclical policy, but we observe a strong heterogeneity among provinces and over time. We follow Frankel et al.'s (2013) classification to illustrate graduation among Chinese provinces.

We find that about one third of the provinces were able to avoid or escape from the procyclicality bias. These are the so-called recent and established graduates. The recent graduates group includes 6 provinces (Gansu, Guizhou, Inner Mongolia, Qinghai, Shaanxi, and Sichuan) that reduced the degree of pro-cyclicality over time. They have "graduated" from pro-cyclical expenditure (significant positive $\hat{\beta}_{i}$ ) before the reform to countercyclical spending (significant negative $\hat{\beta}_{i}$ ) or acyclical (insignificant $\hat{\beta}_{i}$ ) after 1994 . The established graduates group includes 5 provinces (Heilongjiang, Jilin, Ningxia, Xinjiang, and Zhejiang)

that have always been countercyclical (significant negative $\hat{\beta}_{i}$ ) or acyclical (insignificant $\hat{\beta}_{i}$ ). The rest of the provinces can be categorized into the so-called still-in-school and back-toschool groups. The still-in-school group comprises 6 provinces (Beijing, Chongqing, Guangdong, Hunan, Shanghai, and Shanxi) for which pro-cyclicality 
continued after the reform (significant positive $\hat{\beta}_{i}$ before and after 1994). The back-to-school group is quantitatively the biggest (13 provinces: Anhui, Fujian, Guangxi, Hainan, Hebei, Henan, Hubei, Jiangsu, Jiangxi, Liaoning, Shandong, Tianjin, and Yunnan) and is characterized by an amplification of the pro-cyclicality of public expenditure. These provinces were countercyclical (significant negative $\hat{\beta}_{i}$ ) or acyclical (insignificant $\hat{\beta}_{i}$ ) before 1994 and pro-cyclical (significant positive $\hat{\beta}_{i}$ ) after the reform.

See Table 6.

\subsection{Driving factors}

In this section, we study the determinants of the cyclicality of provincial expenditure. We first estimate the time varying $\beta$ coefficient from equation (3). As evidenced above, procyclicality is the prominent feature of provincial public spending. The average estimated coefficient is 0.5 . In Figure 1, about 92 percent province-year observations of the estimated $\hat{\beta}_{i}$ are found to be associated with procyclical stance. We therefore proceed by estimating equation (4) depending on data availability. The sample size is constrained by the availability of the data, especially information on corruption, government efficiency, and the NERI index (see Section IV). ${ }^{16}$ The Tibet province is excluded because of the lack of data on the drivers. Results are reported in Table 7.

As expected, when the financial constraints are relaxed (an increase in the loan-to-deposit ratio) fiscal policy becomes less pro-cyclical for the period 1978-2013. The corresponding estimated coefficient is negative and statistically significant at the 1 percent level. A one standard deviation increase in the loan-to-deposit ratio is associated with about 21.6 percent decrease in the average pro-cyclicality. It is worth noting that the loan-to-deposit variable becomes insignificant statistically when the quality of institution is controlled for on the shorter sample. This might reflect a strong correlation between the financial development and the quality of institution generating a collinearity bias.

Among the political factors, only the RPL appears to be significant: we find that the coefficient associated with RPL is negative. A longer RPL induces the leader to pursue a more prudent fiscal policy. A one standard deviation increase in the RPL is associated with about 13 to 16 percent decrease in the average pro-cyclicality. However, the RPL is no longer significant when the quality of institution is controlled for on the shorter sample. This suggests that the effect of the RPL on the cyclicality of provincial expenditure operates through the quality of institutions.

The quality of the institutions is found to be a key mitigating factor of a pro-cyclical fiscal

\footnotetext{
${ }^{16}$ To ensure that endogeneity is not concern in the estimates, we also re-estimate equation (4) with one year lagged covariates. Our results remained unchanged. Results are available upon request.
} 
policy. Because of data limitations, we are only able to cover the quality of institutions for the 1998-2013 period. Provinces with more corruption cases are characterized by stronger pro-cyclicality. The estimated coefficient is positive, statistically significant at the 10 percent level. A one standard deviation increase in the corruption index is associated with about 4 to 4.5 percent increase in the average pro-cyclicality. In the same vein, pro-cyclicality of public spending is lower when governments can efficiently deliver public goods and services and address corruption. We find that a higher government efficiency is negatively and statistically associated with the cyclicality coefficient. A one standard deviation increase in the government efficiency index is associated with about 11 percent decrease in the average pro-cyclicality.

Structural factors are found to be significant drivers of the cyclicality of provincial spending. As expected, government size is negatively and significantly associated with lower procyclicality. The estimated coefficient is negative, statistically significant at the 10 percent level. Large provincial governments tend to embark on countercyclical policy (lower procyclicality) which is associated with lower growth volatility (as evidenced by van den Noord 2000). The level of development significantly lowers pro-cyclicality during the most recent period (1998-2013).

The remaining suspected variables are not statistically significant. The marketization index is not significant. Provinces that are more affected by shocks, proxied by the output volatility, are not more prone to pro-cyclical spending. Trade openness does not significantly impact cyclicality as well as the lagged deficit to GDP ratio.

See Table 7 and See Figure 1.

\section{Conclusion}

This paper has examined the cyclicality of China's provincial expenditures. We made two original contributions. First, we document the pro-cyclical characteristics of provincial expenditure. This underlines the sub-optimality of sub-national fiscal policy in terms of stabilizing local economies. In all the provinces, fiscal policy does not smooth the business cycle. A disaggregated approach shows that pro-cyclicality is widespread across all budgetary items. More importantly, the increased autonomy of provincial leaders has heightened the pro cyclical behavior of fiscal policy. However, there is a group of provinces, about one-third, that were able to escape the pro-cyclicality bias. Second, we explore the drivers of the pro-cyclical behavior. We find that fiscal policy is less pro-cyclical in provinces with large governments and relatively better access to credit. Institutional factors are also important. The fact that the RPL of local governors is negatively associated with fiscal pro-cyclicality may reflect that local officials with shorter RPL are more likely to adopt rent-seeking behavior in good times (voracity effect suggested by Tornell and Lane, 1999). The pro-cyclicality is also reduced by good quality institutions: lower incidence of corruption and stronger government efficiency. In the context of a slowdown of economic growth and the growing debt of the Chinese provinces, mitigating the procyclicality bias could be 
welfare improving. This can be achieved through containing of local public sector, developing the local financial sector, controlling more closely the actions of local officials with shorter time in office, and strengthening of institutions including combatting corruption and firming the efficiency of public service delivery. 


\section{References}

Aghion, P., and I. Marinescu, 2008, "Cyclical Budgetary Policy and Economic Growth: What Do We Learn from OECD Panel Data?” In NBER Macroeconomics Annual 2007, 22 , edited by Daron Acemoglu, Kenneth Rogoff, and Michael Woodford. Chicago: University of Chicago Press.

Alesina, A., F. R. Campante, and G. Tabellini, 2008, "Why is Fiscal Policy Often ProCyclical?” Journal of the European Economic Association, 6(5), pp. 1006-36.

Ambrose, B., Y. Deng and J. Wu, 2015, "Understanding the risk of China's local government debts and its linkage with property markets", mimeo, National University of Singapore. Available at http://dx.doi.org/10.2139/ssrn.2557031

Ang, A., J. Bai, and H. Zhou, 2016, "The Great Wall of Debt: Real Estate, Political Risk, and Chinese Local Government Credit Spreads", Columbia Business School Research Paper No. 15-57. Available at SSRN: https://ssrn.com/abstract=2603022.

Beck, N., and J. N. Katz. 2011. Modeling dynamics in time-series-cross-section political economy data. Annual Review of Political Science, 14, pp. 331-52.

Birney M., 2014, "Decentralization and Veiled Corruption under China's Rule of Mandates," World Development, 53, pp. 55-67.

Caballero R. J. and A. Krishnamurthy, 2004, "Fiscal Policy and Financial Depth," NBER Working Papers No. 10532, National Bureau of Economic Research.

Calderón, C., Duncan, R., and Schmidt-Hebbel, K., 2004, "Institutions and Cyclical Properties of Macroeconomic Policies," Central Bank of Chile Working Paper. 285, Santiago, Chile.

Calderón, C., R. Duncan, K. Schmidt-Hebbel, 2012, “Do Good Institutions Promote CounterCyclical Macroeconomic Policies?” Globalization and Monetary Policy Institute Working Paper 118, Federal Reserve Bank of Dallas.

Carmignani, F. and J. S. Laurenceson, 2013, "Provincial Business Cycles and Fiscal Policy in China," Economics of Transition, 21(2), pp. 323-40.

Christiano, Lawrence, Eichenbaum, Martin, Rebelo, Sergio, 2011, "When is the Government Spending Multiplier Large?” Journal of Political Economy, 119(1), pp. 78-121.

Cole, M., R. Elliott, and J. Zhang, 2009, "Corruption, Governance and FDI Location in China: A Province-Level Analysis," Journal of Development Studies, 45(9), pp. 1494-1512.

Eyraud, L., and Lusinyan, L., 2013, "Vertical Fiscal Imbalances and Fiscal Performance in Advanced Economies," Journal of Monetary Economics, 60 (5), pp. 571-87. 
Fan G., X. Wang, and H. Zhu, 2010. NERI Index of Marketization of China's

Provinces-The Report on the Relative Process of Marketization of Each Region in China, Economics Science Press.

Feltenstein, A. and S. Iwata, 2005, "Decentralization and Macroeconomic Performance in China: Regional Autonomy Has Its Costs," Journal of Development Economics, 76(2), pp. 481-501.

Frankel, J. A., C. A. Végh, and G. Vuletin, 2013, “On Graduation from Fiscal ProCyclicality,” Journal of Development Economics, 100(1), pp. 32-47.

Gavin, M., and R. Perotti, 1997, "Fiscal Policy in Latin America," NBER Macroeconomics Annual, 12, pp. 11-72, MIT Press.

Ilzetzki, E., and C. A. Végh, 2008, "Pro-cyclical Fiscal Policy in Developing Countries: Truth or Fiction?" NBER Working Papers No. 14191, National Bureau of Economic Research.

Jia J., Q. Guo and J. Zhang, 2014, "Fiscal Decentralization and Local Expenditure Policy in China," China Economic Review 28, 107-122.

Kaminsky, G. L., C. M. Reinhart, and C. A. Végh., 2005, "When it Rains, it Pours: Procyclical Capital Flows and Macroeconomic Policies,'NBER Macroeconomics Annual, 19, pp. 11-82.

Lane, Philip R., 2003, "The Cyclical Behavior of Fiscal Policy: Evidence from the OECD," Journal of Public Economics, 87(12), pp. 2661-75.

Li, Y. and F. Wu 2012, "The Transformation of Regional Governance in China: The Rescaling of Statehood," Progress in Planning, 78, pp. 55-99.

Montinola, G., Qian Y. and B. R. Weingast, 1995, "Federalism, Chinese Style: The Political Basis for Economic Success in China," World Politics, 48, pp. 50-81.

Naughton, B., and Dali Yang, ed., 2010, "Holding China Together: Introduction," In Naughton and Yang, ed., Holding China Together: Diversity and National Integration in the Post-Deng Era. New York: Cambridge University Press.

Nickell S., 1981, "Biases in Dynamic Models with Fixed Effects”, Econometrica, 49(6), pp. 1417-26.

Rodden, J. and E. Wibbels. 2010, "Fiscal Decentralization and the Business Cycle: An Empirical Study of Seven Federations," Economics and Politics, 22, pp. 37-67.

Rodrik, D. 1998. “Why Do More Open Economies Have Bigger Governments?” Journal of Political Economy 106 (5), pp. 997-1032. 
Roodman, D.M., 2009, “A Note on The Theme of Too Many Instruments”, Oxford Bulletin of Economics and Statistics, 71(1), pp. 135-58.

Talvi, E. and C. A. Vegh, 2005, "Tax Base Variability and Pro-Cyclical Fiscal Policy in Developing Countries,” Journal of Development Economics, 78(1), pp. 156-90.

Thornton, J., 2008, “Explaining Pro-cyclical Fiscal Policy in African Countries," Journal of African Economies, 17(3), pp. 451-64.

Tornell, A, and P R. Lane. 1999. "The Voracity Effect,” American Economic Review, 89(1), pp. 22-46.

van den Noord, P. 2000, "The Size and Role of Automatic Fiscal Stabilizers in the 1990s and Beyond”, OECD Working Paper 230.

Xu, C., 2011, “The fundamental Institutions of China's Reform and Development," Journal of Economic Literature, 49(4), pp. 1076-1151.

Zhang, Y. S. and S. Barnett, 2014, "Fiscal Vulnerabilities and Risks from Local Government Finance in China," IMF Working Paper WP 14/4 (Washington: International Monetary Fund). 


\section{Tables}

\begin{tabular}{|c|c|c|c|c|c|}
\hline Variable & Mean & Standard Deviation & Minimum & Maximum & Observations \\
\hline$\Delta$ Log Git & 0.158 & 0.112 & -0.393 & 0.554 & 963 \\
\hline$\Delta$ Log Yit & 0.151 & 0.062 & -0.031 & 0.416 & 963 \\
\hline Yit-Yit ${ }^{\star}$, Hodrick-Prescott & 0.001 & 0.138 & -0.491 & 0.460 & 877 \\
\hline Yit-Yit*, Baxter-King & -0.001 & 0.031 & -0.103 & 0.097 & 825 \\
\hline Yit-Yit", Christiano-Fitzgerald & -0.264 & 0.257 & -0.740 & 0.349 & 877 \\
\hline$\Delta$ Log Yit $>Y^{*}$ & 0.094 & 0.105 & 0.000 & 0.416 & 963 \\
\hline$\Delta \log Y i t \leq Y^{*}$ & 0.057 & 0.059 & -0.031 & 0.169 & 963 \\
\hline Time-varying $\beta$ coefficient, total expenditure & 0.606 & 0.491 & -0.889 & 3.235 & 926 \\
\hline Time-varying $\beta$ coefficient, current expenditure & 0.484 & 0.408 & -1.020 & 1.480 & 737 \\
\hline Time-varying $\beta$ coefficient, capital expenditure & 0.546 & 1.395 & -6.570 & 5.328 & 704 \\
\hline Loan-to-Deposit ratio & 0.917 & 0.292 & 0.401 & 2.265 & 926 \\
\hline Implicit Deficit-to-GDP & -0.048 & 0.091 & -0.469 & 0.525 & 926 \\
\hline Turnover governor & 0.237 & 0.425 & 0.000 & 1.000 & 926 \\
\hline Tenure governor & 2.071 & 2.057 & 0.000 & 12.000 & 926 \\
\hline Remaining Political Life governor & 5.519 & 5.346 & -9.000 & 30.000 & 926 \\
\hline Corruption Cases & 3.334 & 1.006 & 1.740 & 7.030 & 180 \\
\hline Government Efficiency & 0.000 & 0.257 & -0.640 & 0.860 & 180 \\
\hline Marketization Index (NERI) & 5.626 & 1.893 & 2.190 & 10.380 & 300 \\
\hline Government size & 0.150 & 0.070 & 0.049 & 0.592 & 926 \\
\hline Trade openness & 0.233 & 0.344 & 0.002 & 3.689 & 926 \\
\hline Output Volatilty & 0.257 & 0.083 & 0.055 & 0.501 & 910 \\
\hline Log. GDP pc & 8.340 & 1.410 & 5.287 & 11.377 & 926 \\
\hline
\end{tabular}

Source: Authors.

Table 2: Cyclicality of Provincial Expenditure, 1978-2013

Dependent Variable: Total Expenditure $(\Delta$ Log Git)

\begin{tabular}{|c|c|c|c|c|}
\hline & \multicolumn{4}{|c|}{ Dependent Variable: Total Expenditure ( $\Delta$ Log Git) } \\
\hline & \multicolumn{2}{|c|}{ Generalized method of moments (GMM) } & \multicolumn{2}{|c|}{ Within fixed effects } \\
\hline & Difference & System & & \\
\hline & (1) & (2) & (3) & (4) \\
\hline \multirow[t]{2}{*}{$\Delta$ Log Yit } & $0.308^{* * *}$ & $0.313^{* * *}$ & $0.440^{* * *}$ & $0.416^{* \star *}$ \\
\hline & $(0.086)$ & $(0.084)$ & $(0.069)$ & $(0.069)$ \\
\hline \multirow[t]{2}{*}{$\Delta$ Log Git-1 } & $0.142^{* *}$ & $0.137^{\star}$ & 0.045 & .. \\
\hline & $(0.067)$ & $(0.068)$ & $(0.040)$ & .. \\
\hline Province fixed effects & Yes & Yes & Yes & Yes \\
\hline Year fixed effects & Yes & Yes & Yes & Yes \\
\hline Observations & 932 & 963 & 963 & 994 \\
\hline R2 & $\ldots$ & $\ldots$ & 0.665 & 0.664 \\
\hline Provinces & 31 & 31 & 31 & 31 \\
\hline Instruments & 37 & 40 & .. & .. \\
\hline Hansen & 1.000 & 1.000 & .. & .. \\
\hline AR(1) & 0.000 & 0.000 & .. & .. \\
\hline$A R(2)$ & 0.123 & 0.115 & .. & \\
\hline
\end{tabular}

Note: Intercept included. Arellano-Bond's (1991) difference and system generalized method of moments.

Robust standard errors are in parentheses. The Hansen test evaluates the validity of the instrument set; that is, tests for over-identifying restrictions. AR (1) and AR (2) are the Arellano-Bond autocorrelation tests of first and second order (the null is no autocorrelation), respectively.Standard errors in parentheses. ${ }^{* * *}$ $p<0.01,{ }^{* *} p<0.05,{ }^{*} p<0.1$. 
Table 3: Cyclicality of Components of Expenditure, 1978-2013

\begin{tabular}{cccccccc}
\hline & \multicolumn{9}{c}{ Within fixed effects } \\
\cline { 2 - 7 } Categorie of expenditure & $\beta$ & $\mathrm{SD}(\beta)$ & $\mathrm{N}$ & $\mathrm{R} 2$ & Provinces & $\begin{array}{c}\text { Province } \\
\text { fixed effects }\end{array}$ & $\begin{array}{c}\text { Year fixed } \\
\text { effects }\end{array}$ \\
\cline { 2 - 8 } Current Expenditure & $0.367^{* * *}$ & $(0.064)$ & 786 & 0.489 & 31 & Yes & Yes \\
Agriculture support & $0.365^{* * *}$ & $(0.132)$ & 789 & 0.388 & 31 & Yes & Yes \\
Social systems & $0.338^{* * *}$ & $(0.062)$ & 819 & 0.402 & 31 & Yes & Yes \\
Administration & $0.602^{* * *}$ & $(0.089)$ & 811 & 0.556 & 31 & Yes & Yes \\
Capital Expenditure & $0.432^{* *}$ & $(0.173)$ & 742 & 0.468 & 31 & Yes & Yes \\
$\quad$ Capital construction & $0.442^{* *}$ & $(0.167)$ & 798 & 0.483 & 31 & Yes & Yes \\
Innovation funds & 0.033 & $(0.298)$ & 742 & 0.284 & 31 & Yes & Yes \\
\hline
\end{tabular}

Note: Intercept included. Standard errors in parentheses. ${ }^{* * *} p<0.01,{ }^{* *} p<0.05,{ }^{*} p<0.1$.

Table 4: Cyclicality of Provincial Expenditure and Growth Regime, 1978-2013

\begin{tabular}{|c|c|c|c|}
\hline \multirow[b]{2}{*}{ Dependent Variable ( $\Delta$ Log Git) } & \multicolumn{3}{|c|}{ Within fixed effects } \\
\hline & Total Expenditure & Current Expenditure & Capital Expenditure \\
\hline & $(1)$ & $(2)$ & (3) \\
\hline \multirow[t]{2}{*}{$\Delta \log$ Yit $>Y^{*}$} & $0.417^{\star \star *}$ & $0.373^{* * *}$ & $0.441^{* *}$ \\
\hline & $(0.068)$ & $(0.069)$ & $(0.181)$ \\
\hline \multirow[t]{2}{*}{$\Delta \log Y i t \leq Y^{*}$} & $0.418^{* \star *}$ & $0.389^{* * *}$ & $0.461^{*}$ \\
\hline & $(0.079)$ & $(0.097)$ & $(0.234)$ \\
\hline Province fixed effects & Yes & Yes & Yes \\
\hline Year fixed effects & Yes & Yes & Yes \\
\hline Observations & 994 & 786 & 742 \\
\hline Provinces & 31 & 31 & 31 \\
\hline $\mathrm{R} 2$ & 0.664 & 0.489 & 0.468 \\
\hline
\end{tabular}

Note: Standard errors in parentheses. ${ }^{* * *} p<0.01,{ }^{* *} p<0.05,{ }^{*} p<0.1$.

Table 5: Impact of 1994 Reform, 1978-2013

\begin{tabular}{|c|c|c|c|}
\hline \multirow{3}{*}{ Dependent Variable ( $\Delta$ Log Git) } & \multicolumn{3}{|c|}{ Within fixed effects } \\
\hline & \multirow[t]{2}{*}{ Total Expenditure } & Current Expenditure & \multirow{2}{*}{$\begin{array}{r}\text { Capital Expenditure } \\
\text { (3) }\end{array}$} \\
\hline & & $(2)$ & \\
\hline \multirow[t]{2}{*}{$\Delta$ Log Yit } & 0.230 ** & $0.248^{* * *}$ & 0.139 \\
\hline & $(0.089)$ & $(0.073)$ & $(0.215)$ \\
\hline \multirow[t]{2}{*}{ Dummy for 1994 reform } & $-0.190 * * *$ & $-0.183^{\star * *}$ & $-0.464^{* * *}$ \\
\hline & $(0.025)$ & $(0.036)$ & $(0.097)$ \\
\hline \multirow[t]{2}{*}{$\Delta$ Log Yit* Dummy for 1994 reform } & $0.455^{* * *}$ & $0.358^{* * *}$ & $0.799^{* *}$ \\
\hline & $(0.133)$ & $(0.099)$ & $(0.388)$ \\
\hline Province fixed effects & Yes & Yes & Yes \\
\hline Year fixed effects & Yes & Yes & Yes \\
\hline Observations & 994 & 786 & 742 \\
\hline Provinces & 31 & 31 & 31 \\
\hline $\mathrm{R} 2$ & 0.670 & 0.495 & 0.472 \\
\hline
\end{tabular}

Note: Intercept included. Standard errors in parentheses. ${ }^{* *} p<0.01,{ }^{* *} p<0.05,{ }^{*} p<0.1$. 
Table 6: Cyclicality by Province: Testing for Graduation, 1978-2013

\begin{tabular}{|c|c|c|c|c|c|c|c|c|c|}
\hline Province & & $197 \varepsilon$ & & & & $1994-$ & & & Status \\
\hline & $\beta$ & $\mathrm{SD}(\beta)$ & $\mathrm{N}$ & $\mathrm{R} 2$ & $\beta$ & $\mathrm{SD}(\beta)$ & $\mathrm{N}$ & $\mathrm{R} 2$ & \\
\hline Beijing & $1.734^{* *}$ & $(0.769)$ & 16 & 0.206 & $1.488^{* * *}$ & $(0.349)$ & 18 & 0.683 & Still in school \\
\hline Chongqing & $2.652^{\star \star *}$ & $(0.210)$ & 8 & 0.955 & $0.438^{\star *}$ & $(0.178)$ & 18 & 0.245 & Still in school \\
\hline Guangdong & $0.985^{\star}$ & $(0.428)$ & 9 & 0.296 & $0.605^{\star *}$ & $(0.226)$ & 17 & 0.268 & Still in school \\
\hline Hunan & $1.114^{* *}$ & $(0.454)$ & 16 & 0.283 & $0.554^{*}$ & $(0.266)$ & 18 & 0.324 & Still in school \\
\hline Shanghai & $1.475^{\star}$ & $(0.791)$ & 16 & 0.178 & $1.230^{* * *}$ & $(0.191)$ & 18 & 0.776 & Still in school \\
\hline Shanxi & $0.792^{\star \star \star}$ & $(0.244)$ & 15 & 0.340 & $0.376^{\star *}$ & $(0.156)$ & 18 & 0.163 & Still in school \\
\hline Anhui & -0.433 & $(0.850)$ & 9 & 0.282 & $1.031^{\star * *}$ & $(0.107)$ & 17 & 0.738 & Back to school \\
\hline Fujian & 0.803 & $(0.458)$ & 16 & 0.200 & $0.956^{\star \star \star}$ & (0.109) & 18 & 0.773 & Back to school \\
\hline Guangxi & 0.719 & $(0.522)$ & 16 & 0.116 & $0.368^{*}$ & $(0.202)$ & 18 & 0.187 & Back to school \\
\hline Hainan & 0.431 & $(0.453)$ & 14 & 0.199 & $1.066^{\star \star \star}$ & (0.305) & 18 & 0.473 & Back to school \\
\hline Hebei & 1.100 & (0.959) & 9 & 0.159 & $0.505^{\star \star \star}$ & $(0.144)$ & 18 & 0.365 & Back to school \\
\hline Henan & -0.347 & $(0.529)$ & 16 & 0.059 & $0.527^{\star \star \star}$ & $(0.121)$ & 18 & 0.399 & Back to school \\
\hline Hubei & 0.527 & $(0.551)$ & 16 & 0.043 & $0.637^{\star}$ & $(0.313)$ & 18 & 0.223 & Back to school \\
\hline Jiangsu & 0.618 & $(0.943)$ & 16 & 0.056 & $0.717^{\star \star \star}$ & $(0.113)$ & 18 & 0.658 & Back to school \\
\hline Jiangxi & 0.757 & $(0.489)$ & 9 & 0.279 & $0.618^{\star *}$ & $(0.209)$ & 17 & 0.368 & Back to school \\
\hline Liaoning & 0.316 & $(0.951)$ & 8 & 0.155 & $0.725^{\star \star \star}$ & $(0.243)$ & 18 & 0.385 & Back to school \\
\hline Shandong & -0.442 & $(0.789)$ & 16 & 0.074 & $0.675^{\star \star \star}$ & $(0.174)$ & 18 & 0.485 & Back to school \\
\hline Tianjin & -0.308 & $(0.538)$ & 16 & 0.014 & $0.674^{\star \star *}$ & $(0.194)$ & 18 & 0.417 & Back to school \\
\hline Yunnan & 0.282 & $(0.456)$ & 15 & 0.244 & $0.575^{\star \star \star}$ & $(0.169)$ & 17 & 0.369 & Back to school \\
\hline Gansu & $1.526^{\star \star *}$ & $(0.263)$ & 16 & 0.423 & -0.0443 & $(0.112)$ & 18 & 0.032 & Recent graduates \\
\hline Guizhou & $1.454^{\star \star *}$ & $(0.401)$ & 16 & 0.443 & 0.467 & $(0.386)$ & 18 & 0.140 & Recent graduates \\
\hline Inner Mongolia & $0.605^{\star}$ & $(0.304)$ & 9 & 0.158 & 0.286 & $(0.222)$ & 18 & 0.101 & Recent graduates \\
\hline Qinghai & $0.726^{*}$ & $(0.348)$ & 15 & 0.280 & -0.515 & $(0.478)$ & 18 & 0.195 & Recent graduates \\
\hline Shaanxi & $1.231^{\star \star \star}$ & $(0.245)$ & 16 & 0.487 & 0.473 & $(0.317)$ & 17 & 0.144 & Recent graduates \\
\hline Sichuan & $0.731^{* *}$ & $(0.217)$ & 8 & 0.162 & 0.379 & $(0.367)$ & 18 & 0.046 & Recent graduates \\
\hline Heilongjiang & 1.758 & $(1.236)$ & 16 & 0.190 & 0.256 & $(0.252)$ & 18 & 0.068 & Established graduates \\
\hline Jilin & 0.244 & $(0.509)$ & 16 & 0.030 & 0.413 & $(0.254)$ & 18 & 0.136 & Established graduates \\
\hline Ningxia & 1.444 & $(1.353)$ & 16 & 0.149 & 0.376 & $(0.412)$ & 18 & 0.032 & Established graduates \\
\hline Xinjiang & 0.278 & $(0.757)$ & 16 & 0.009 & 0.301 & $(0.435)$ & 18 & 0.029 & Established graduates \\
\hline Zhejiang & 1.633 & $(1.087)$ & 9 & 0.356 & 0.0242 & $(0.145)$ & 17 & 0.141 & Established graduates \\
\hline
\end{tabular}


Table 7: Determinants of the Cyclicality of Provincial Expenditure, 1978-2013 Weighted Least Squares

\begin{tabular}{|c|c|c|c|c|}
\hline & \multirow{2}{*}{\multicolumn{4}{|c|}{ Dependent Variable: Time-Varying Cyclicality ( $\beta$ it) }} \\
\hline & & & & \\
\hline & \multicolumn{2}{|c|}{$1978-2013$} & \multicolumn{2}{|c|}{$1998-2003$} \\
\hline & $(1)$ & $(2)$ & $(3)$ & $(4)$ \\
\hline \multirow[t]{2}{*}{ Log. GDP pc } & 0.610 & 0.549 & $-0.660^{*}$ & $-0.947^{* *}$ \\
\hline & $(0.435)$ & $(0.459)$ & $(0.356)$ & $(0.435)$ \\
\hline \multirow[t]{2}{*}{ Government size } & $-2.541^{* *}$ & $-2.283^{*}$ & $-0.981^{*}$ & $-1.283^{* *}$ \\
\hline & $(1.101)$ & $(1.150)$ & $(0.535)$ & $(0.580)$ \\
\hline \multirow[t]{2}{*}{ Trade openness } & -0.158 & -0.192 & -0.0982 & -0.116 \\
\hline & $(0.120)$ & $(0.119)$ & $(0.0705)$ & $(0.0738)$ \\
\hline \multirow[t]{2}{*}{ Output Volatilty } & & -0.316 & & 0.785 \\
\hline & & $(0.785)$ & & $(0.512)$ \\
\hline \multirow[t]{2}{*}{ Loan-to-Deposit ratio } & $-0.473^{* *}$ & $-0.433^{* *}$ & -0.0841 & -0.0816 \\
\hline & $(0.184)$ & $(0.197)$ & $(0.0920)$ & $(0.0858)$ \\
\hline \multirow[t]{2}{*}{ Implicit Deficit-to-GDP (-1) } & 0.139 & -0.154 & -0.398 & -0.285 \\
\hline & $(0.897)$ & $(0.946)$ & $(0.516)$ & $(0.513)$ \\
\hline \multirow[t]{2}{*}{ Turnover } & 0.0555 & 0.0145 & -0.0138 & -0.0147 \\
\hline & $(0.0387)$ & $(0.0283)$ & $(0.0164)$ & $(0.0156)$ \\
\hline \multirow[t]{2}{*}{ Tenure } & -0.00199 & -0.00420 & 0.0000214 & -0.00101 \\
\hline & $(0.0138)$ & $(0.0119)$ & $(0.00554)$ & $(0.00529)$ \\
\hline \multirow[t]{2}{*}{ Remaining Political Life } & $-0.0185^{\star *}$ & $-0.0148^{* *}$ & -0.000810 & -0.000674 \\
\hline & $(0.00761)$ & $(0.00708)$ & $(0.00347)$ & $(0.00313)$ \\
\hline \multirow[t]{2}{*}{ Corruption Cases } & & & $0.0234^{*}$ & $0.0265^{*}$ \\
\hline & & & $(0.0137)$ & $(0.0133)$ \\
\hline \multirow[t]{2}{*}{ Government Efficiency } & & & $-0.276^{\star *}$ & $-0.256^{* *}$ \\
\hline & & & $(0.102)$ & $(0.0990)$ \\
\hline \multirow[t]{2}{*}{ Marketization Index (NERI) } & & & -0.0343 & -0.0225 \\
\hline & & & $(0.0362)$ & $(0.0328)$ \\
\hline Province fixed effects & Yes & Yes & Yes & Yes \\
\hline Year fixed effects & Yes & Yes & Yes & Yes \\
\hline Observations & 926 & 910 & 180 & 180 \\
\hline Provinces & 30 & 30 & 30 & 30 \\
\hline $\mathrm{R} 2$ & 0.645 & 0.624 & 0.982 & 0.983 \\
\hline
\end{tabular}

Note: Standard errors in parentheses. ${ }^{* * *} p<0.01,{ }^{* *} p<0.05,{ }^{*} p<0.1$. 


\section{Figures}

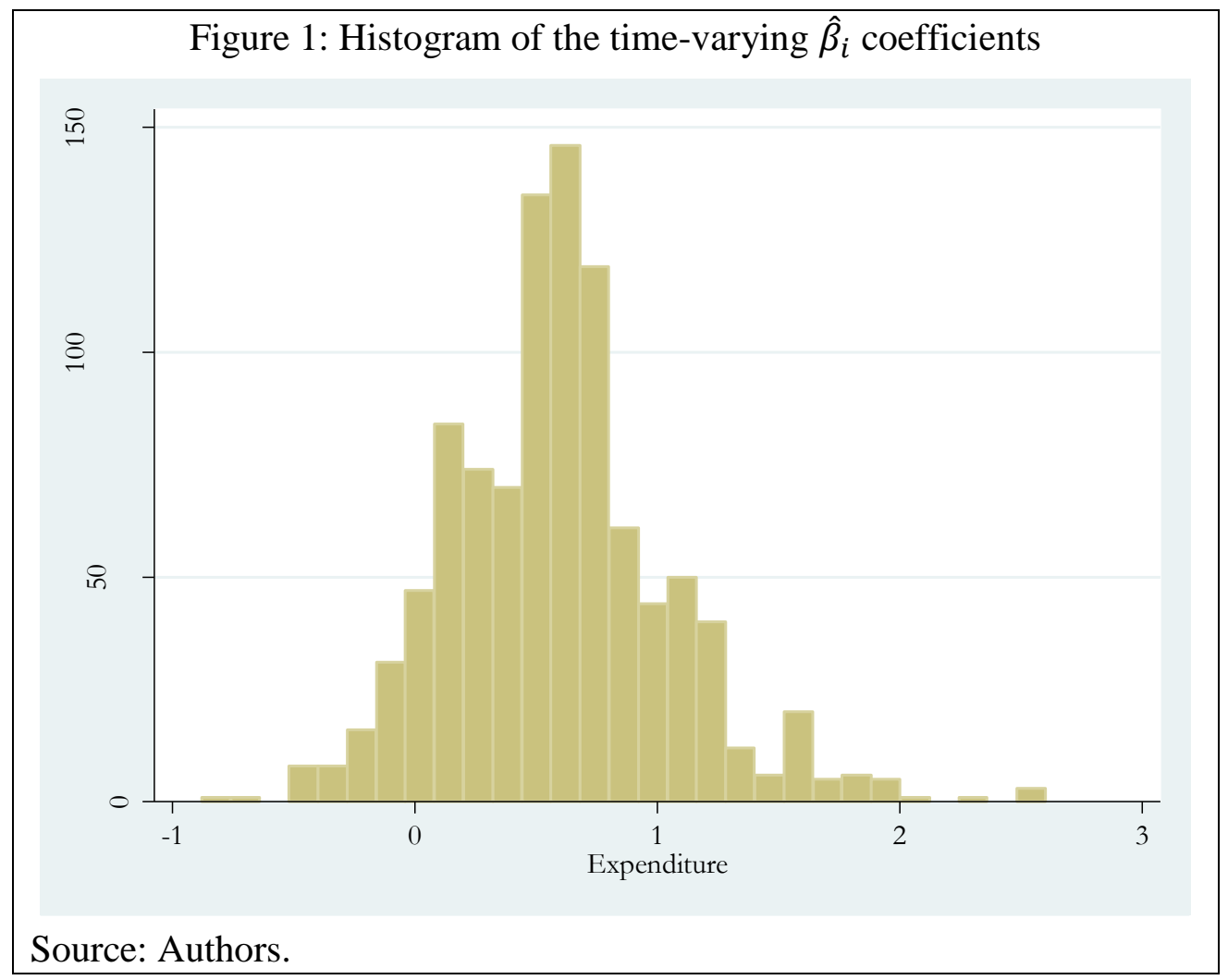

\section{Appendices}

Appendix 1: Cyclicality of Provincial Expenditure 1978-2013, Use of lagged output growth

\begin{tabular}{lcc}
\hline & \multicolumn{2}{c}{ Within fixed effects } \\
\cline { 2 - 3 }$\Delta$ Log Yit-1 & $(1)$ & $(2)$ \\
\cline { 2 - 3 }$\Delta$ Log Yit & $0.222^{* * *}$ & $0.165^{* * *}$ \\
& $(0.062)$ & $(0.055)$ \\
&.. & $0.428^{* * *}$ \\
Province fixed effects &.. & $(0.070)$ \\
Year fixed effects & & \\
Observations & Yes & Yes \\
R2 & Yes & Yes \\
Provinces & 963 & 963 \\
Note: Intercept included. Standard errors in parentheses. ${ }^{* * *} \mathrm{p}<0.01,{ }^{* *} \mathrm{p}<0.05,{ }^{*} \mathrm{p}<0.1$. & 31
\end{tabular}


Appendix 2 : Cyclicality of Provincial Expenditure, 1978-2013, alternative filters Dependent Variable: Total Expenditure (Git-Git*)

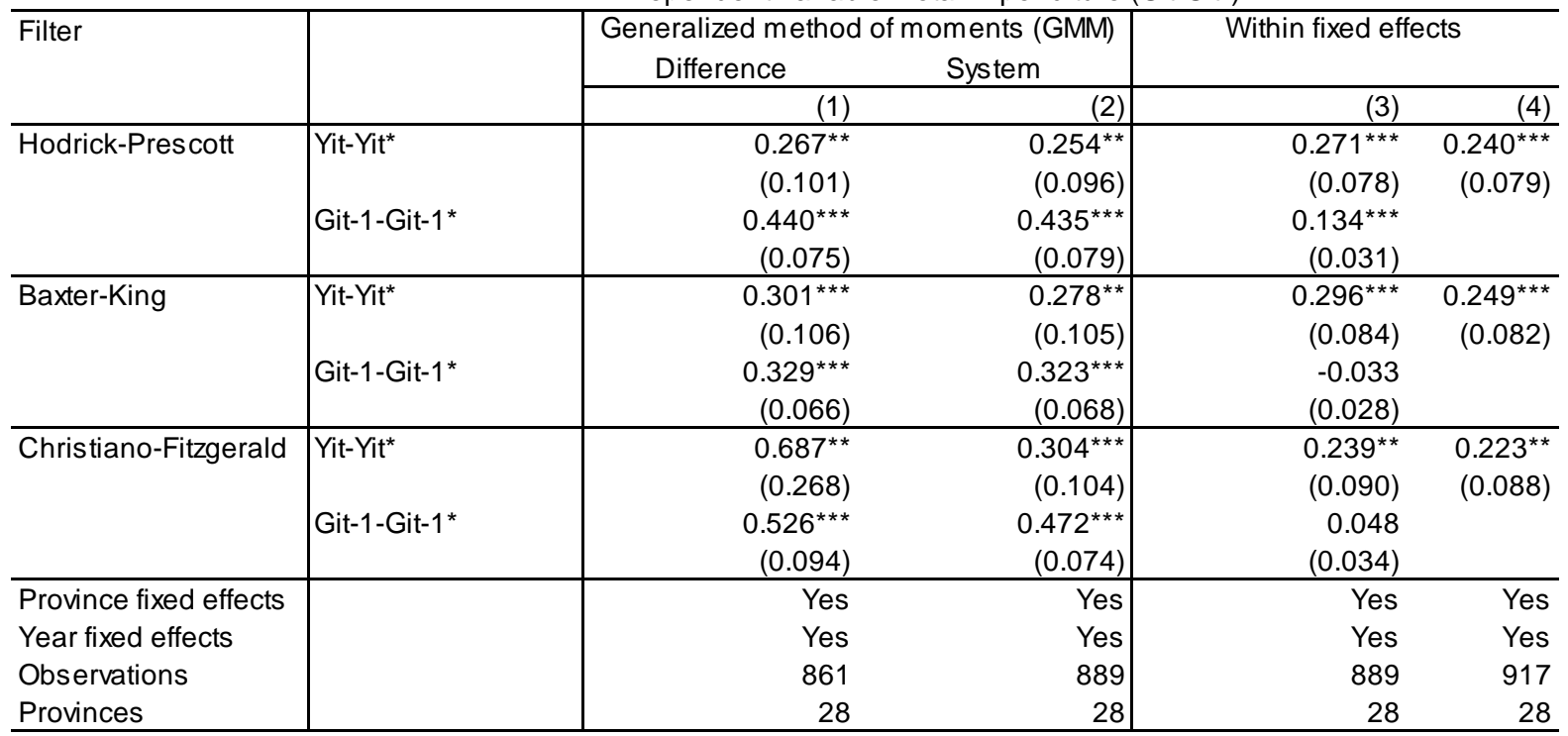

Note: Intercept included. Arellano-Bond's (1991) difference and system generalized method of moments. Robust standard errors are in parentheses. The Hansen test evaluates the validity of the instrument set; that is, tests for overidentifying restrictions. AR (1) and AR (2) are the Arellano-Bond autocorrelation tests of first and second order (the null is no autocorrelation), respectively.Standard errors in parentheses. ${ }^{* *} p<0.01,{ }^{* *} p<0.05,{ }^{*} p<0.1$. 